\title{
THE EFFORT OF IMPROVING THE ACTIVITY AND ABILITY OF STUDENTS IN WRITING REVIEW TEXT THROUGH FILM AT SMA NEGERI 1 PUNGGUR CENTRAL LAMPUNG
}

\author{
By \\ Peni Asih \\ English teacher of SMAN 1 PUNGGUR CENTRAL LAMPUNG \\ peniasih20@gmail.com
}

\begin{abstract}
The objectives of this classroom action research are to improve the students' activity and ability in writing review text at class XII IPA 1 semester 2 of SMA N 1 Punggur. This research uses a film as a medium which is aimed to make the students of XII IPA 1 easy in writing a review text. The researcher uses two cycles in her research which consists of 2 meetings in each cycle. Cycle I uses a short story in its meeting and cycle II uses a film in its meeting. The result shows that the average score of students who gained passing grade (74) or above in cycle I is $56,67 \%$ and in cycle II is $76,6 \%$ while there is $43,33 \%$ of students who get under 74 in cycle I and $23,34 \%$ in cycle II. It means that their average score in writing a review text using film has increased. The students have made a good progress after being given treatment by using film as medium of instruction. This is because film can make the students active during teaching learning process. The result of this study implies that teaching learning process using film improve the students 'ability in writing a review text. Therefore, this media is recommended to be used in the process of teaching learning English especially review text.
\end{abstract}

Keywords : Film, Review Text, Writing,

\section{INTRODUCTION}

Writing skill is one of four skills that must be taught and developed in English learning. Most of the students feel that writing skill is difficult for them so, they are not active in teaching learning process. They think that if they want to get good score in English writing skill, they have to master grammar well and possess a lot of vocabularies .Based on the average score of the students' daily test of writing at class XII IPA 1 SMA N 1 Punggur Central Lampung, only 13 students or $(43.33 \%$ )get passing grade score 74 or above. This result is still far from the teacher's target about $75 \%$ of students get score of passing grade or above.

By seeing from the fact above, surely that there are many factors that affect that condition such as: first, factors that come from students themselves. Most of students feel difficult to translate written text of English into Indonesian, so they are afraid of getting wrong to write. They also have lack of grammar and lack of understanding the plot of story as well. Second, factors that come from the teacher. 
Most of English teachers only give example orally in explaining the material of review text without giving chance to the students to apply it in their process of learning first. This make the students confuse when they are asked to write review text.

"By seeing the difficulties of the students, the researcher try to make classroom action research at class XII IPA 1 SMAN 1 Punggur entitled " The effort of improving the activity and ability of students in writing review text through film at class XII IPA 1 semester 2 of SMA N 1 Punggur Central Lampung year 2015/2016”.

This research is aimed to : (1) Improve the ability of writing review text at class XII IPA 1 , second semester of SMA N 1 Punggur, and (2) Improve the activity of students in writing review text at class XII IPA 1 second semester of SMA N 1 Punggur

\section{RESEARCH OF METHOD}

\section{The setting of research.}

The location of the research is at SMAN Punggur Central Lampung. It was scheduled for full research period from the arrangement of proposal in January, $2^{\text {nd }}$ and $3^{\text {rd }}$ week to the preparation of learning administration and media of learning in January the $4^{\text {th }}$ week and February the $1^{\text {st }}$ week. This study applied some cycles; the first cycle and reflection on February $2^{\text {nd }}$ and 3 rd week. The application of the cycle II and reflection was on February $3^{\text {rd }}$ and $4^{\text {th }}$ week.. The analysis of data was done on February $3^{\text {rd }}$ and $4^{\text {th }}$ week and the $1^{\text {st }}$ of March while the discussion of the result was on February the $4^{\text {th }}$ week and the $1^{\text {st }}$ and the $2^{\text {nd }}$ week of March. The arrangement of final report was on the $3^{\text {rd }}$ and the $4^{\text {th }}$ week of March.

\section{Subject and object of the research.}

The subject of the research is the students of class XII IPA 1 of SMA N 1 Punggur Central Lampung which consists of 30 Students. The object of the research is the improvement of activity and the ability of writing review text at class XII IPA 1 SMA N 1 Punggur Central Lampung, $2^{\text {nd }}$ Semester year 2015/2016.

\section{Source of Data.}

The data was taken from the students in form of ability in writing review text and data of students activity in learning of each cycle. Teacher's partner contributed to the data gathering by 
observing and taking notes about the activity of students during the teaching learning process in each cycle. So the data forms are the quantitative and qualitative: score and learning process.

\section{Technique and tool of collecting data.}

The data of students' activities is described in the form of observation instrument sheet taken from the observation by the partner and researcher during the teaching learning process in each cycle. To get data of students' ability in writing text review using film, the researcher uses performance test in the form of assessment rubric. The sheet of teaching preparation is used to get data of teaching learning process which is done by teacher's partner or an observer.

\section{Validation of the data.}

Validation of data which is used by the researcher is triangulation of data. In this form. the data which is taken from the researcher is combined with the data from the researcher's partner, so it can form valid data.

\section{Analysis of the data.}

Analysis of the data uses triangulation of data, it means that data is collected by seeing data of students' s learning activity, data of learning process, data of students' ability in writing review text. In this case researcher compares the students' score in the first cycle with those in the second cycle. Based on the comparison of both cycles it can been seen the students' score has increased.

\section{Indicator of job quality.}

The measurement of students' learning activity is suited with the condition at SMA N 1 Punggur. If at least $75 \%$ of students are active in following teaching learning process, the researcher thinks that the target has been achieved. While the result of students' ability in writing review text can be seen from the result of writing review test. The students' have to get score at least 74 ( minimum criteria standard ). The criteria of writing assessment are: Grammar, Vocabulary, Coherence.

\section{Procedures of Action.}

This research is planned to be carried out in 2 cycles . Each cycle has 2 meetings. The $1^{\text {st }}$ meeting is done in February the $2^{\text {nd }}$ week and the $4^{\text {th }}$ week. Steps of research are as follows: 
a. Preparation. It is done in February 2016 the second and the third week. Action of the first cycle It is done in February the $2^{\text {nd }}$ week. There are many steps in the Action of the first cycle:

1) Planning

The activities of this steps are:

a) Making instrument of research and supporting facilities.

b) Making daily journal to write teaching learning process note which is happening.

c) Preparing rubric of evaluation to know the result of students' ability in writing review text.

d) Following up and analysing $1^{\text {st }}$ cycle.

e) Determining follow up and making reflection.

2) Action of the research.

There are many steps in this part:

a) Doing performance test to know the result of students' score.

b) Doing the teaching learning process.

c) Doing performance test to know how far the students' progress.

d) The ability of writing is gotten when the teaching learning process is happening.

e) Analysing data of students' writing result and the reflection of teaching learning process.

f) Recommending the result of students' writing assessment and observing to the next cycle.

3) Observation

In this part, the researcher collaborate with partner to do action by using observation sheet.

In this activity the researcher's partner has to fill observation sheet after doing observation during teaching learning process.

\section{4) Reflection}

In the reflection part, the researcher analyses a whole steps of action to be developed in the next cycle.

1. The action of cycle 2

Cycle 2 is done in February the $4^{\text {th }}$ week. In this part, there are many steps must be done :

1) Planning

a) Repairing teaching administration such as : RPP (lesson plan ) and students' worksheet.

b) Repairing assessment of research and supporting facilities.

c) Making daily journal for the second $\left(2^{\text {nd }}\right)$ cycle to write the activity of teaching learning process which is happening.

d) Determining follow up and reflection of the second $\left(2^{\text {nd }}\right)$ cycle.

2) Action of the activities. 
There are many steps in this part:

a) Doing the teaching learning process.

b) Asking the students' difficulties during the teaching learning process.

c) Doing the second test of writing review text using media of film.

d) Doing the second $\left(2^{\text {nd }}\right)$ test of writing review text using media of film. Analysing the ability of students' writing after teaching learning process.

e) Doing evaluation and second $\left(2^{\text {nd }}\right)$ reflection.

f) Giving recommendation due to the result of evaluation and observation to make valid data.

\section{3) Observation}

In this activity, the researcher collaborates with the researcher's partner to do action by using sheet of students' activity observation and observation in the teaching learning process, and the result of the students' writing.

4) Reflection

In the reflection activity, the researcher analyses a whole action in the second cycle to be compared with the result of the first cycle. The final report is done in May the first week.

\section{RESULT AND DISCUSSION}

\section{Final Report.}

The result is written in final report which is legalized by the headmaster in June the second week.

\section{The result of action and discussion}

1. The activity of students learning in the writing aspect.

Class XII IPA 1 consists of 30 students, 25 male students and 6 female students.

Based on the first data, the ability of writing skill in this class is very low. There are only 13 students or only 66, $61 \%$ get minimum standard score. The minimum standard score is 74 . The low result is surely caused by 2 factors, one of them is lack of students' activity in expressing their ideas orally.

When the process of learning is happening in which the researcher is giving many kinds of learning models, most students are not serious in giving attention. They are busy doing many things that does not support the process of teaching learning process. There are also many factors that affect the situation such as : the atmosphere of the class, the noisy of the class, the boredom of the students' feeling that leads them to talk to other friends etc. 
Seeing those reasons, the researcher tries to use film because the students feels enjoy and they are easy to understand the content of the film.

2. The ability of writing review text at class XII IPA 1

Based on the first data got by the researcher, the ability of students in writing review text in class XII IPA 1 is very low, This is caused not only comes from inactive students but also comes from the researcher. For example: model of teaching learning focuses on the researcher. Even, the researcher is rarely giving freedom to the students to look for their own ideas that makes the students have no self-confidence.

By using the material of short story in the first cycle, the students are asked to evaluate short story given based on the material of review text has been taught. The ability of students in understanding English text with a lot of vocabularies are still very low.

That's why, students have low ability to comprehend the content of short story which is given by the teacher that affect the result of their writing score.

3. The Result of cycle 1

a. Planning of the action

In planning step, the researcher starts by making preparation of teaching learning ( RPP) with competency standard : writing . The content of competency standard is "understanding and responding the meaning of monolog text using kinds of oral language which is used accurately, fluently and acceptably in the context of daily life in the form of narrative and review text"

After that the researcher prepares observation format to see the activity of the teacher and the format of students' activity observation during the process of teaching and learning. In the action of cycle 1, the researcher asks her partner, other English teacher to help her. After that, the researcher prepares assessment rubric to know the ability of students in writing review text.

b. Application of the action

Cycle 1 is carried out on Wednesday and Saturday, February 11 and 14, 2016. The allocation of time are: Wednesday 2 x 45 minutes and Saturday 2 X 45 minutes. Before the teaching learning process done, the researcher gives format of observation of teacher's teaching preparation to the English teacher's partner. Then, in the teaching learning process, she involves two other English teachers as observer to follow her to the classroom. Both of 
them are asked to observe the students' activity during the class and to fill the format of students' activity. The next, teacher does the process of teaching learning based on the following steps:

1) Pre- Activity.

a. Apperception

1) Praying

2) Check the students' attendance

3) Ask the students' condition

4) Tell the objective of subject

5) Asking and answer things related to the subject

b. Motivation

- Explain the importance of the material which will be learnt and competency that should be mastered by the students.

2) Main- Activity.

a. Exploration of the teacher's activity in exploration are :

1) Give example of short story to the students.

2) Students try to comprehend the short story given.

3) Teacher gives example of expressing content and plot of review text based on short story given.

4) Teacher gives many questions based on short story and language features of review text.

b. Elaboration

Teacher's activities in this part are:

1) The teacher turns on the film in language laboratory;

2) Give the time to the students to express content and plot of the film in review text;

3) .Students describes the content of the film to make review text based on the generic structure.

c. Confirmation.

The teacher's activity in confirmation are:

1) Asking and answering generic structure of review text, language features, plot and content of the film give;

2) Together with the students, concluding things related to review text.

3). Post activity.

The teacher's activity in post- Activity are :

1) Ask students' ability in understanding review text.

2) Ask students to look for the film, then write it in review text for the next meeting.

3) Together with the students, teacher makes conclusion about the material. 


\section{Result of cycle 2 .}

a. Planning of learning.

Planning which is done by the teacher and observer in the second cycle are as follows;

1) Preparing concept of material learning which is arranged in the first cycle.

2) Creating the purpose of learning to be achieved.

3) Preparing planning of remedial teaching.

4) Preparing instrument of students' activity observation, rubric of learning and rubric of learning evaluation.

5) Preparing media of learning that will be used in the process of teaching learning process.

6) Collaborating with partner or observer and explaining about the way of filling observation format.

b. Action of Learning

Cycle I

1) The teacher does teaching learning based on learning scenario which aims to repair the weaknesses the process of learning in cycle 1.

2) Students follow the steps of learning process activity and try to repair the weaknesses in cycle. The observer observes the process of learning based on sheet of learning process observation.

\section{Result of observation}

a) The result of students' learning activity.

After being done observation of learning process in cycle 1, shown in attachment 1 , the result of activity indicator divided into 3 parts : 1) interest and motivation, 2) asking and question or discussion. Interest and motivation in cycle 1, the first meeting is 50,00\% while in the second meeting increases become $56,67 \%$ while the target is $75,00 \%$.

Asking and answer or discussion of the first meeting is $53.33 \%$, the second meeting increases to be $56,67 \%$ while the target is $75 \%$. Writing is done through the process which have many steps. In the first meeting it is $56,6 \%$ and the second meeting is $63,33 \%$, while the target is $75 \%$.

The example given by the teacher in the first meeting is $56,67 \%$, there is no improvement. The score of assessing friend's writing and the ability of self writing objectively in the first meeting is $46,67 \%$ while at the second meeting increases to be 53,33 $\%$ with target $75 \%$. Doing reflection in every process of writing in the first meeting is $66,67 \%$ and the second meeting increases to be $73,33 \%$ with the target $75 \%$. 
b) Result of observation of students' writing ability.

Result of students' writing ability in cycle 1 can be seen in attachment 8 with category, pass or get 74 or above consists of 17 students or $56,67 \%$ while category failed or gets under 74 consists of 13 students or $43,33 \%$ with the target of $75 \%$.

c) Result of observation cycle 2

Result of students' activity observation.

After being done observation of students' activity in the second cycle which is done in two meetings, the result of indicator students' activity can be seen on attachment 9 with the following details:

Interest and motivation of students' learning

Interest and motivation of students' learning at the first meeting is $80.00 \%$ and at the second meeting is $90,32 \%$ and the target is $80 \%$. The idea development or self-experience at the first meeting is $83,87 \%$ and at the second meeting is $87,01 \%$ and the target is $80 \%$.

d) Question and answer or discussion at the first meeting is $80,65 \%$, the second meeting is $87,01 \%$ the target is $70 \%$. Writing is done through process which is done step by step chronologically. At the first meeting is $83,87 \%$, and at the second meeting is $\mathrm{r} 83,87 \%$ with the target is $75 \%$. Writing activity is done by showing model or example given by the teacher at the first meeting is $77,42 \%$, and the second meeting is $83,87 \%$ the target is $80 \%$.

e) Assessment of writing other friend and ability of self writing objectively.

Assessment of writing other friend and ability of self writing objectively. At the first meeting is $74,19 \%$, at the second meeting is , the target is $70 \%$.

f) Doing Reflection.

Doing reflection is started from analysing the film to evaluation, At the first meeting is $74,19 \%$, the second meeting is $74,19 \%$ target $75 \%$.

g) Result of students' writing ability.

Learning achievement of the students at the first cycle can be seen in attachment 9 with the following category:

1) Pass > 74 consists of 17 Or $56,67 \%$

2) Fail, score $<74$ consists of 13 students or $29,03 \%$ 
3) The target is $75 \%$. Learning achievement of the students at the second cycle can be seen in attachment 11 with the following category:

4) Pass > 74 consists of 23 or $76,67 \%$

5) Fail, score $<74$ consists of 7 students or $23,34 \%$

6) The target is $75 \%$.

h) The result of Action

The result of reflection got from the result of reflection in the discussion are as follow. The activity of students' learning run well. Learning of writing review text using film can improve the activity of students at Class XII IPA 1 the second semester of SMA N 1 Punggur. All of the aspects of students' activity have increased significantly. The activity of students in writing skill is low at first then improves at last. In addition, the ability of students' writing improved. Through the film the ability of writing review text at class XII IPA 1 SMA N 1 Punggur increases significantly.

\section{Conclusion}

1. Teaching learning process using film in the aspect of writing skill can improve students' activity at class XII IPA 1 SMAN 1 Punggur year 2015/ 2016

2. Teaching learning process using film in the aspect of writing skill can improve students' ability at class XII IPA 1 SMAN 1 Punggur year 2015/ 2016

\section{Suggestion}

1. English teachers should use film in teaching writing especially in the material of review text because film can improve students' activity.

2. English teachers are recommended to use film in teaching writing especially in the material of review text because film can improve students' ability in writing.

\section{BIOPROFILE}

Peni Asih, S.Pd. (bachelor of arts in English Education) received her undergraduate degree in English Education from the State University of Lampung in 1999. Before that she was a DII of English alumnus graduated in 1991 from the same university. Since 2000 she has been a civil servant and assigned to work at Junior High School ( SMPN 2) Seputih Banyak Central Lampung with her NIP. 196904052000122003. She had spent and dedicated her time there for three years before she proposed to move to SMAN 1 Punggur Central Lampung in 2004. Since 
then she has been a definitive English teacher with her interest in writing up to now. Her corresponding email:peniasih20@gmail.com

\section{REFERENCES}

Allsop, Jake.(1989).Cassell's Student's English Grammar : Oxford University Press.

Carr, Wand Kemmis, S. (1986).Becoming Critical : Knowing through Action Research Victoria : Deakin University Press.

Depdikbud. (2004). Sillabus Bahasa Inggris Kurikulum Tingkat Satuan Pendidikan : Jakarta Depdikbud. (2004). Buku petunjuk penilaian kurikulum tingkat satuan pendidikan : Jakarta Dalman, H. (2012). Menulis Karya Ilmiah : Bandar Lampung. Raja Grafindo Persada Bima,Bachtiar;Kurniawati, Cicik;Susiningsih.(2016).PR Bahasa Inggris: Jakarta IntanPariwara Hornby, A.S. (2002). Oxford Advanced Learner's dictionary. Oxford: Oxford University Press Anderson, M., K. Anderson. (2003). Text Types in English 2. Australia : MacMilan Education Australia Pty Ltd. 